\title{
Authorization of vehicles for placing in service after modernization and renewal. European and national requirements
}

Vehicles moving on railway lines, sidings etc. are subject to the inevitable ageing processes and elements used in them are subject to the processes of wearing. Over the years of operation of the vehicle the regulations and requirements, that must met by a vehicle subjected to the process of obtaining the authorization for placing into service, also change. Therefore, modernization and renewal of vehicles is an important element in the life of the vehicle allowing them to operate with the latest design solutions.

The article presents the current Polish regulations under both community law and national law. It shows the possible ways of conducting for placing the vehicles after modernization and renewal. It presents the common elements and differences arising from the community and national law to carry out the process of replacing in service of the vehicle after the modernization and renewal.

\section{Dopuszczenie pojazdów do eksploatacji po modernizacji i odnowieniu - wymagania europejskie i krajowe}

\begin{abstract}
Pojazdy poruszajace sie po liniach kolejowych, bocznicach itp. podlegaja nieuchronnym procesom starzenia a zastosowane $w$ nich elementy ulegaja procesom zużycia. Na przestrzeni lat eksploatacji pojazdu zmieniaja się również przepisy oraz wymagania jakie musi spetniać pojazd poddany procesowi uzyskania dopuszczenia do ruchu. Modernizacja i odnowienie pojazdów jest więc istotnym elementem $w$ życiu pojazdu pozwalajac na ich eksploatację z najnowocześniejszymi rozwiazaniami konstrukcyjnymi.

$W$ artykule zaprezentowano obowiqzujace $w$ Polsce przepisy prawne wynikajace zarówno prawa wspólnotowego oraz z prawa krajowego. Przedstawiono możliwe drogi postepowania dla dopuszczania pojazdów po modernizacji i odnowieniu. Zaprezentowano elementy wspólne oraz rozbieżności wynikajace z prawa wspólnotowego oraz krajowego dla przeprowadzenia procesu ponownego wtaczenia do eksploatacji pojazdu po przeprowadzonej modernizacji i odnowieniu.
\end{abstract}

\section{WSTĘP}

Pojazd kolejowy jest zaprojektowany tak, by mógł być eksploatowany przez kila dziesięcioleci. Jest to okres niezmiernie długi. Rozwój techniki powoduje, że wyprodukowane kilka dziesięcioleci temu pojazdy stają się przestarzałe. W trakcie użytkowania pojazdu przychodzi taki moment, kiedy należy postawić pytanie o dalszy los pojazdu. Właściciel pojazdu musi podjąć decyzję czy modernizować lub odnawiać posiadane pojazdy, czy zakupić nowe.

Jednym $\mathrm{z}$ istotnych kryteriów jest cena pojazdu. W artykule [4] porównano koszty modernizacji pojazdu EN57 i zakupu nowego taboru. Analiza przeprowadzona przez autora pokazuje, że modernizacja pojazdów około dwukrotnie tańsza niż zakup nowego taboru. Do właścicieli taboru należy decyzja czy poddać modernizacji lub odnowieniu dwa pojazdy, które po modyfikacji muszą spełniać przepisy obowiązujące $\mathrm{w}$ dniu przystąpienia do modernizacji lub odnowienia,

\section{INTRODUCTION}

Railway vehicle is designed so that it could be operated for a few decades. It is a very long period. The development of technology makes that the vehicles, which were produced a few decades ago, become obsolete. For each user of the vehicle comes a time when he needs to ask himself what to do next. The owner of vehicle must decide between modernization or renewal of the owned vehicles and buying the new ones. One of the important criteria is the price of the vehicle. The article [4] compares the modernization costs of vehicle EN57 with purchase of the new rolling stock. The analysis conducted by the author shows that the modernization of the vehicle is about twice cheaper than purchasing the new rolling stock. The owners of rolling stock must decide whether to modernize or renew two vehicles, which after modification must comply with the rules applicable at the date of entering to the modernization or renewal, or purchase 
czy zakupić jeden pojazd nowy. Przez modernizację nie należy rozumieć tylko modyfikacji podjętej na pojazdach kilkunasto lub kilkudziesięcioletnich. Może ona dotyczyć także nowych pojazdów, np. gdy użytkownik podejmie decyzję o rozbudowie składów elektrycznych zespołów trakcyjnych o dodatkowe człony.

Na rysunku 1 przedstawiono widok zewnętrzny pojazdu typu EN57 przed modernizacją i po modernizacji wykonanej przez ZNTK Mińsk Mazowiecki dla Szybkiej Kolei Miejskiej w Trójmieście. Na rys. 2 przedstawiono wnętrze pojazdu EN57 przed i po modernizacji.

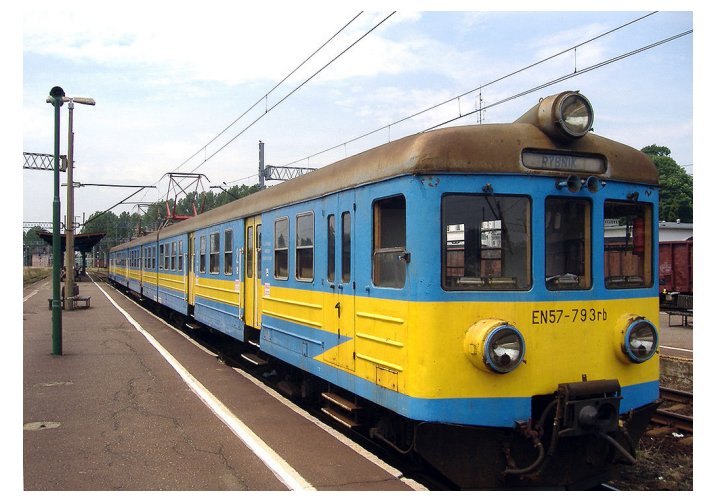

a new vehicle. By modernizing it should not be understood only modification of between ten and twenty years or decades vehicles. It can also concern the new vehicles, e.g. when the user decides to expand the electric multiple units with the additional segments.

Figure 1 shows an external view of a vehicle of type EN57 before and after modernization made by ZNTK Mińsk Mazowiecki for the Fast City Train (SKM) in Tricity. Figure 2 shows the interior of the vehicle EN57 before and after modernization.

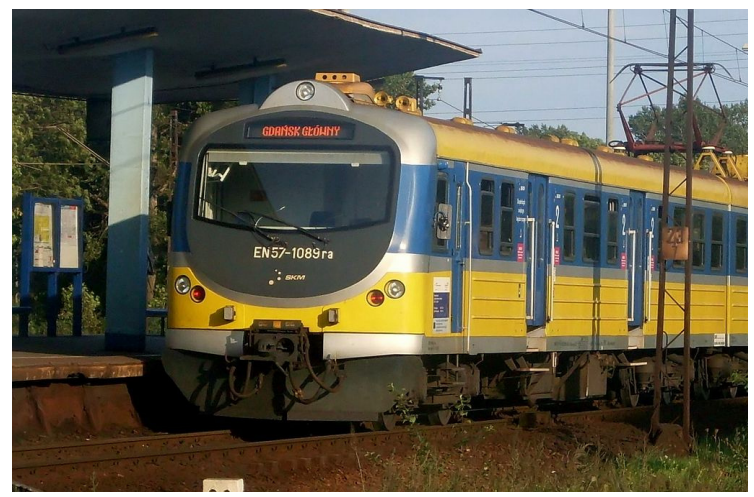

Rys. 1 - Elektryczny zespół trakcyjny przed i po modernizacji [1]

Fig. 1 - Electric multiple unit before and after modernization [1]


Rys. 2 - Wnętrze EN57 przed i po modernizacji [2, 3]

Fig. 2 - Interior of EN57 before and after modernization [2, 3]

Przed modernizowanymi pojazdami stoi jeszcze jedno zadanie. Spełnienie wymagań obowiązujących w dniu ich ponownego dopuszczenia do eksploatacji lub przynajmniej udowodnienie, że zmiany wprowadzone $\mathrm{w}$ modernizowanych pojazdach poprawiaja bezpieczeństwo i zbliżają je do wymagań obecnie obowiązujących.

\section{PRZEPISY WSPÓLNOTOWE}

Przepisy krajowe biorą swój początek w prawie wspólnotowym, które ostatecznie powinno doprowadzić do ujednolicenia przepisów na terenie Unii Europejskiej. Podstawą funkcjonowania kolei we Wspólnocie są dwie dyrektywy:
For the modernized vehicles is one more task. Fulfillment of the requirements applicable at the date of their re-placing in service or at least proving that the changes introduced in the modernized vehicles improve the safety and approach them to the requirements applicable currently.

\section{COMMUNITY REGULATIONS}

National regulations have their origin in Community law, which finally should lead to unify the regulations within the European Union. The basis of functioning of the Community's railways are two directives: 
- Dyrektywa Parlamentu Europejskiego i Rady 2008/57/WE z dnia 17 czerwca 2008 r. w sprawie interoperacyjności systemu kolei we Wspólnocie [5]

- Dyrektywa 2004/49/WE Parlamentu Europejskiego i Rady z dnia 29 kwietnia 2004 r. w sprawie bezpieczeństwa kolei wspólnotowych oraz zmieniająca dyrektywę Rady 95/18/WE w sprawie przyznawania licencji przedsiębiorstwom kolejowym, oraz dyrektywę 2001/14/WE w sprawie alokacji zdolności przepustowej infrastruktury kolejowej i pobierania opłat za użytkowanie infrastruktury kolejowej oraz certyfikację w zakresie bezpieczeństwa [6].

Obie dyrektywy opisuja jak powinno być skonstruowane prawo krajowe, aby bezpiecznie wprowadzać do eksploatacji zarówno nowy tabor jak i tabor modernizowany. Przepisy Unii Europejskiej [5] podaja określenia zarówno dla modernizacji jak i odnowienia. Zgodnie z [5] w artykule 2 możemy znaleźć definicje:

- „modernizacja” oznacza wszelkie większe prace modyfikacyjne prowadzone $\mathrm{w}$ podsystemie lub jego części, poprawiające całkowite osiągi podsystemu

- „odnowienie” oznacza wszelkie większe prace wymienne w podsystemie lub jego części, niezmieniające całkowitych osiagów podsystemu.

Definicje te zostały przeniesione do prawa krajowego i można je znaleźć w Ustawie o transporcie kolejowym [7]. Niestety w żadnym $\mathrm{z}$ powyższych dokumentów nie wyjaśniono, co precyzyjnie oznacza sformułowanie ,całkowite osiagi podsystemu”.

Modernizacja (odnowienie) pojazdu zawsze powinna prowadzić do poprawy bezpieczeństwa i komfortu zarówno podróżnych jak i obsługi pojazdu. Zgodnie z przepisami tabor $\mathrm{w}$ Polsce można podzielić na trzy główne kategorie:

- tabor zgodny z Technicznymi Specyfikacjami Interoperacyjności (TSI)

- tabor niezgodny z Technicznymi Specyfikacjami Interoperacyjności

- tabor przeznaczony na bocznice, dla metra, linie wydzielone oraz na linie o szerokości mniejszej niż $1435 \mathrm{~mm}$.

Dla poszczególnych kategorii pojazdów stosowane są odpowiednie przepisy, w których można znaleźć sposób postępowania z pojazdami poddanymi modernizacji lub odnowieniu. Wszystkie zasady postępowania przytoczone $\mathrm{w}$ dokumentach opierają się na dyrektywach i spełnieniu wymagań zasadniczych, czyli wymagań odnoszących się do bezpieczeństwa, niezawodności, dostępności, zgodności technicznej itp. W artykule 5 dyrektywy [5] postawiono wymaganie, iż „podsystemy muszą stosować się do TSI obowiązujących w chwili dopuszczenia ich do eksploatacji, ich
- Directive of the European Parliament and Council 2008/57/EC of 17 June 2008. on the interoperability of the Community rail system [5],

- Directive 2004/49/EC of the European Parliament and Council of 29 April 2004. on safety of the Community's railways and amending the Council Directive 95/18/EC on the licensing of railway undertakings and Directive 2001/14/EC on the allocation of railway infrastructure capacity and charges for the use of railway infrastructure and safety certification [6].

Both directives describe how it should be formulated national law to safely place in operation both the new and the modernized rolling stock. The regulations of the European Union [5] give definitions both for the modernization and renewal. According to [5] in Article 2, we can find definitions:

- „modernization” means any bigger modification works conducting in the subsystem or its part which improve the overall performance of the subsystem;

- „renewal” means any bigger replaceable works in the subsystem or its part not changeable the overall performance of the subsystem

These definitions have been transferred into national law and they can be found in the Act on railway transport [7]. Unfortunately, none of these documents explain what precisely is meant by "the overall performance of the subsystem".

Modernization (renewal) of the vehicle should always lead to improvement of safety and comfort for both passengers and personnel of the vehicle. In accordance with the regulations the rolling stock in Poland can be divided into three main categories:

- Rolling stock compatible with the Technical Specifications for Interoperability (TSI),

- Rolling stock incompatible with the Technical Specifications for Interoperability,

- Rolling stock intended for the sidings, metro, dedicated lines and lines with a width less than $1435 \mathrm{~mm}$.

For individual categories of vehicles the relevant regulations are used, in which it can be found a way of dealing with vehicles subjected to modernization or renewal. All regulations of conducting, cited in documents, are based on the directives and fulfillment of the essential requirements, it is requirements relating to safety, reliability, availability, technical compliance, etc. In Article 5 of the Directive [5] it is given the requirement that "subsystems must conform to the TSI applicable at the time of their commissioning, modernization or renewal in accordance with this Directive; this compliance shall be permanently main- 
modernizacji lub odnowienia, zgodnie $\mathrm{z}$ niniejszą dyrektywa; zgodność ta będzie stale utrzymywana w okresie działania każdego z podsystemów". Wymaganie to jednoznacznie stawia warunek, że modernizacja lub odnowienie muszą spełniać kryteria zgodnie $\mathrm{z}$ obowiązująca TSI. Wymaganie to może być niezmiernie trudne do spełnienia szczególnie w przypadku gdy modernizacji poddawany jest pojazd wyprodukowany kilkadziesiąt lat temu. Dla takich przypadków dyrektywa [5] przewiduje odstępstwa zapisane w artykule 9:

1. Jeżeli nie zachodza $w$ wtaściwe szczególne przypadki, państwo czlonkowskie nie musi stosować jednej lub kilku TSI zgodnie z niniejszym artykulem $w$ nastęujacych przypadkach:

a) w przypadku planowanego nowego podsystemu, w przypadku odnowienia lub modernizacji istniejacego już podsystemu lub $w$ przypadku jakiegokolwiek elementu, o którym mowa w art. 1 ust. 1 , będacego na zaawansowanym etapie realizacji lub będqcego przedmiotem realizowanego kontraktu w momencie publikacji TSI

b) w przypadku projektu dotyczqcego odnowienia lub modernizacji istniejqcego już podsystemu, jeśli skrajnia tadunku, prześwit toru, szerokość międzytorza lub napięcie sieci elektrycznej $w$ tych TSI nie sq zgodne z tymi istniejacymi już $w$ podsystemie

c) $w$ przypadku planowanego nowego podsystemu lub planowanego odnowienia lub modernizacji istniejacego już podsystemu na terytorium tego państwa członkowskiego, którego sieć kolejowa jest oddzielona lub odizolowana przez morze od sieci kolejowej na pozostatym obszarze Wspólnoty lub oddzielona od niej z uwagi na szczególne uwarunkowania geograficzne

d) w przypadku planowanego odnowienia, rozszerzenia lub modernizacji istniejacego już podsystemu, jeśli stosowanie tych TSI wptynętoby na optacalność ekonomiczna projektu lub zgodność systemu kolejowego państwa członkowskiego.

Pozostałe wymagania artykułu 9 pkt. 1 nie stosują się do modernizacji lub odnowienia. W przytoczonym fragmencie najistotniejsze znaczenie i najczęściej wykorzystywany jest punkt „d” a w szczególności zapis mówiący o opłacalności ekonomicznej projektu. Opłacalność projektu nie może być kryterium bezwarunkowym i nie może powodować negatywnego wpływu na bezpieczeństwo. Aby prawidłowo przeprowadzić modernizację i ocenić wpływ zmian na bezpieczeństwo należy zastosować zapisy z dyrektywy [6], a w szczególności opierającego się na niej Rozporządzenia Wykonawczego Komisji (UE) nr 402/2013 z dnia 30 kwietnia 2013 r. w sprawie wspólnej metody oceny bezpieczeństwa $\mathrm{w}$ zakresie wyceny i oceny ryzyka i uchylające rozporządzenie (WE) nr 352/2009 [7]. Zgodnie z rozporządzeniem tained while operation of each subsystem". This requirement exactly puts a condition that the modernization or renewal must meet the criteria in accordance with the applicable TSI. This requirement can be extremely difficult to be met especially when the subjected to modernization vehicle was produced several decades ago. For such cases, the Directive [5] provides for the exceptions written in Article 9:

1. If the relevant specific cases do not occur, a Member State does not need to apply one or few TSIs in accordance with this Article in the following cases:

a) In the case of planned new subsystem, in case of renewal or modernization of an existing subsystem, or in case of any element referred to in Article 1 paragraph 1, which is at an advanced stage of realization or which is the subject of the contract realized at the time of publication of the TSI;

b) In the case of project concerning the renewal or modernization of an existing subsystem where the loading gauge, track gauge, space between the tracks or electrification voltage in these TSIs are not compatible with those existing in the subsystem;

c) In the case of the planned new subsystem or in case of the planned renewal or modernization of an existing subsystem within the territory of that Member State whose rail network is separated or isolated by the sea from the rail network on the rest of the Community area or separated from it due to the special geographical conditions;

d) In the case of the planned renewal, extension or modernization of an existing subsystem, when the application of these TSIs affected the economic profitability of the project or the compatibility of the rail system of the Member State.

Other requirements of Article 9 point 1 do not apply to modernization or renewal. In the quoted passage the greatest importance and most frequently the point " $\mathrm{d}$ " is used and in particular the provision concerning the economic profitability of the project. The profitability of the project cannot be an unconditional criterion and cannot cause a negative impact on safety. To correctly modernize and assess the impact of changes on the safety, it should be used the provisions of the Directive [6], and in particular based on it the Implementing Regulation (EU) of Commission No 402/2013 of 30 April 2013. on a common method of safety assessment in the field of valuation and risk assessment, and repealing the Regulation (EC) No 352/2009 [7]. According to the Regulation for each change with a technical, operational or organizational character it should be used the common method of 
dla każdej zmiany mającej charakter techniczny, eksploatacyjny lub organizacyjny należy zastosować wspólną metodę oceny bezpieczeństwa $\mathrm{w}$ zakresie wyceny i oceny ryzyka (CSM). Przeprowadzona ocena bezpieczeństwa może doprowadzić do dwóch wyników:

a) zmiana zostaje uznana za znaczącą, stosuje się proces zarządzania ryzykiem określony $\mathrm{w}$ rozporządzeniu [7];

b) zmiana zostaje uznana za nieznaczacca, wystarcza przechowywanie odpowiedniej dokumentacji, która uzasadnia podjętą decyzję.

Niezależnie od typu zmian $\mathrm{i}$ ich charakteru zawsze należy przeprowadzać ocenę zmian i ich wpływu na bezpieczeństwo. Poprawne przeprowadzenie oceny bezpieczeństwa wykaże, w których aspektach można zrezygnować ze spełnienia kryteriów, które stawiane są w TSI. Szczegółowy proces dopuszczenia pojazdu po modernizacji podaje $\mathrm{w}$ artykule 20 rozporządzenie [5] przytoczony poniżej:

Dopuszczanie istniejacych podsystemów do eksploatacji po odnowieniu lub modernizacji:

1. W przypadku odnowienia lub modernizacji podmiot zamawiajacy przekazuje państwu członkowskiemu, którego to dotyczy, dokumentacje opisujaca projekt. Państwo czlonkowskie dokonuje jej analizy i biorac pod uwage strategie wdrożenia wskazana $w$ stosownej TSI, podejmuje decyzje, czy zakres prac oznacza konieczność wydania nowego zezwolenia na dopuszczenie do eksploatacji $w$ rozumieniu niniejszej dyrektywy.

Takie nowe zezwolenie na dopuszczenie do eksploatacji jest wymagane za każdym razem, gdy przewidziane prace moga negatywnie wptynać na ogólny poziom bezpieczeństwa podsystemu. Jezeli jest wymagane nowe zezwolenie, państwo członkowskie podejmuje decyzje, $w$ jakim stopniu TSI powinna być zastosowana do projektu.

Państwo czlonkowskie podejmuje decyzje najpóźniej cztery miesiace po przedlożeniu przez wnioskodawce kompletnej dokumentacji.

2. Jeżeli wymagane jest nowe zezwolenie oraz jezeli TSI nie została $w$ petni zastosowana, państwa czlonkowskie przekazuja Komisji nastęujace informacje:

- przyczyne niepetnego zastosowania danej lub danych TSI,

- parametry techniczne stosowane zamiast TSI,

- organy odpowiedzialne za stosowanie, w przypadku tych parametrów, procedury weryfikacji, o której mowa $w$ art. 18.

3. Komisja przekazuje Agencji informacje, o których mowa w ust. 2, a Agencja je publikuje. safety assessment in the field of valuation and risk assessment (CSM). The carried out safety assessment can lead to two results:

a) the change is accepted as significant, the risk management process defined in Regulation [7] is applied;

b) the change is accepted as insignificant, it is enough to keep the suitable documentation that justifies the taken decision.

Regardless of the type of changes and their character it should be always carried out the assessment of the changes and their impact on safety. The correct carrying out the safety assessment shows in which aspects it is possible to give up fulfillment of the criteria which are placed in the TSI. The detailed process of authorization of the vehicle after modernization for placing in service is provided in Article 20 of Regulation [5] given below:

Authorization of the existing subsystems after renewal or modernization for placing in service

1. In the case of renewal or modernization, the contracting entity shall send a documentation describing the project to the Member State concerned. The Member State analyses it and taking into account the implementation strategy indicated in the applicable TSI, it decides whether the range of works means that a new authorization for placing in service within the meaning of this Directive is necessary.

Such new authorization for placing in service is required every time when the envisaged works can negatively affect the overall safety level of the subsystem. If a new authorization is needed, the Member State shall decide to what extent the TSI should be applied to the project.

Member State shall decide no later than four months after submission of the complete documentation by the applicant.

2. If a new authorization is required and if the TSI is not fully applied, the Member States shall hand over the Commission the following information:

- reason of incomplete application of this or these TSIs,

- technical parameters applying instead of the TSI,

- the bodies responsible for applying, in the case of those characteristics, the verification procedure referred to in Article 18.

3. The Commission hands over the Agency the information referred to in paragraph 2, and the Agency shall publish it. 
Powyższe zapisy z dyrektywy [5] odnoszące się do modernizacji i odnowienia $\mathrm{w}$ pozostawiają swobodę państwom członkowskim w stosowaniu TSI wymagań do pojazdów modernizowanych. Każde odstępstwo winno być udokumentowane i dla każdego odstępstwa należy określić parametry, które pojazd powinien spełniać. Dyrektywy nie są dokumentami prawnymi do stosowania wprost. Szczegółowe i obowiązujące bezpośrednio wymagania można znaleźć w poszczególnych TSI odnoszących się do poszczególnych podsystemów. Wykonując modernizację należy rozpoczać od wymagań zawartych w TSI a następnie po uzasadnieniu możliwości zastosowania odstępstwa zastosować odpowiednie procedury obowiązujące na terenie kraju członkowskiego.

W TSI znajdują się również zapisy dotyczące modernizacji lub odnowienia. Poniżej przedstawiono zapisy $\mathrm{z}$,TSI lokomotywy i tabor pasażerski” [8] odnoszące się zarówno do modernizacji jak i odnowienia:

7.1.2. Odnowienie lub modernizacja istniejacego taboru

\subsubsection{Wprowadzenie}

1) Niniejszy punkt zawiera informacje dotyczace art. 20 dyrektywy 2008/57/WE.

\subsubsection{Odnowienie}

$W$ przypadku odnowienia państwo czlonkowskie musi stosować następujace zasady stanowiqce podstawe stosowania niniejszej TSI:

1) Nowa ocena pod katem wymagań niniejszej TSI jest wymagana tylko dla tych parametrów podstawowych $w$ niniejszej TSI, które mogq ulec zmianie w wyniku danej modyfikacji.

2) W przypadku istniejacego taboru niezgodnego z TSI, jeżeli $w$ trakcie odnawiania nie można spetnić danego wymogu TSI ze względów ekonomicznych, odnowienie jest dopuszczalne, o ile oczywiste jest, że nastapiła poprawa parametru podstawowego $w$ kierunku określonym $w$ TSI.

3) Krajowe strategie migracji zwiazane $z$ wdrażaniem innych TSI (np. TSI obejmujacych instalacje state) moga mieć wplyw na wymagany zakres stosowania niniejszej TSI.

4) W przypadku projektu zawierajacego elementy niezgodne z TSI procedury oceny zgodności oraz weryfikacji WE, które maja być stosowane, powinny być uzgodnione z państwem członkowskim.

5) W przypadku istniejacej konstrukcji taboru niezgodnej z TSI wymiana catego pojazdu kolejowego lub jego poszczególnych pojazdów sktadowych (np. wymiana po poważnym uszkodzeniu; zob. również pkt. 6.2.9) nie wymaga oceny zgodności z niniejsza TSI, pod warunkiem że dany pojazd kolejowy lub jego pojazd sktadowy sq takie same jak te, które zastęuja. Takie pojazdy kolejowe musza być identyfikowalne $i$ certyfikowane zgodnie z przepisami krajowymi
The above provisions of the Directive [5] relating to the modernization and renewal leave the Member States the flexibility in application of TSI requirements for the modernized vehicles. Each exception should be documented and for each exception the parameters, which must be met by the vehicle, must be defined. Directives are not the legal documents to use directly. The detailed and directly applicable requirements can be found in the individual TSI relating to the various subsystems. Carrying out the modernization it should be started with the requirements included in TSI, and next, after justifying the possibility of applying the exception, the appropriate procedures applicable in the area of member state should be applied. The TSI also includes provisions concerning the modernization or renewal.

Below there are the provisions of the "TSI Locomotives and passenger rolling stock" [8] relating to both modernization and renewal.

\subsubsection{Renewal or modernization of existing rolling stock}

\subsubsection{Introduction}

1) This section contains information about art. 20 Directive 2008/57/EC.

\subsubsection{Renewal}

In the case of the renewal the Member State must apply the following rules being the basis for the application of this TSI:

1) A new assessment with paying special attention to the requirements of this TSI is only required for the basic parameters in this TSI which can be changed as a result of the modification.

2) In the case of existing rolling stock incompatible with the TSI if during the renewal the requirement of the TSI for economic reasons cannot be met, the renewal is acceptable as long as it is clear that the basic parameter is improved in the direction specified in the TSI.

3) The domestic migration strategies related to the implementation of other TSIs (e.g. TSIs including the fixed installations) may impact on the required scope of using of this TSI.

4) In the case of a project including elements incompatible with TSI, the conformity assessment procedures and EC verification, which were to be applied, should be agreed with the Member State.

5) In the case of existing design of rolling stock incompatible with the TSI, the replacement of the entire railway vehicle or its individual component vehicles (e.g. replacement after the serious damage; see also paragraph. 6.2.9) does not require the conformity assessment to this TSI, 
bądź międzynarodowymi lub z przyjętymi sposobami postepowania powszechnie uznanymi $w$ dziedzinie kolei.

6) $\quad$ przypadku wymiany pojazdów kolejowych lub poszczególnych pojazdów zgodnych z niniejsza TSI wymagana jest ocena zgodności z niniejsza TSI.

\subsubsection{Modernizacja}

$W$ przypadku modernizacji państwo członkowskie stosuje następujace zasady stanowiqce podstawę stosowania niniejszej TSI:

1) Części i podstawowe parametry podsystemu, na które prace modernizacyjne nie miaty wptywu, sq wytaczone z oceny zgodności z przepisami niniejszej TSI.

2) Nowa ocena pod katem wymagań niniejszej TSI jest wymagana tylko dla tych parametrów podstawowych $w$ niniejszej TSI, które ulegaja zmianie w wyniku danej modyfikacji.

3) W przypadku, gdy w trakcie modernizacji nie można spetnić danego wymogu TSI ze wzgledów ekonomicznych, modernizacja jest dopuszczalna, o ile oczywiste jest, że nastapiła poprawa parametru podstawowego $w$ kierunku określonym w TSI.

4) W instrukcji stosowania znajduja się wskazówki dla państw czlonkowskich dotyczqce tych modyfikacji, które sq uznawane za modernizacyjne.

5) Krajowe strategie migracji zwiazane z wdrażaniem innych TSI (np. TSI obejmujacych instalacje stałe) moga mieć wptyw na wymagany zakres stosowania niniejszej TSI.

6) W przypadku projektu zawierajacego elementy niezgodne z TSI procedury oceny zgodności oraz weryfikacji WE, które maja być stosowane, powinny być uzgodnione z państwem czlonkowskim.

Powyższe zapisy odnoszące się do modernizacji i odnowienia mają status obowiązujący bezpośrednio $\mathrm{w}$ państwie członkowskim. Najważniejszym zapisem dotyczącym zarówno odnowienia jak i modernizacji jest to, że sprawdzenie pojazdu po przeprowadzanej modernizacji winno odbywać się w zakresie zmian wprowadzonych. Oznacza to, że mimo iż niektóre parametry mogą nie spełniać wymagań obowiązujących w momencie podjęcia modernizacji to nie będa podlegać one ocenie. Ocena zmian winna być przeprowadzona kompleksowo w oparciu o wspólną metodę oceny bezpieczeństwa $\mathrm{w}$ zakresie wyceny i oceny ryzyka. Wyniki wyceny i oceny ryzyka prowadza do przeprowadzenia sprawdzeń w układach, w których nie była przeprowadzona zmian. Przykładem mogą być zmiany wnętrza pojazdu poprawiające komfort podróżowania. Wymiana obejmuje wymianę wyłożeń ścian i podłogi, foteli, zabudowę klimatyzatorów zabudowę nowego przedziału WC. Oczywis- provided that the railway vehicle or its component vehicle are the same as those they replace. Such railway vehicles must be identified and certified in accordance with national or international regulations or accepted conducting methods universally accepted in the railway domain.

6) In the case of replacement of rail vehicles or individual vehicles complying with this TSI it is required the assessment of conformity with this TSI.

\subsubsection{Modernization}

In the case of modernization the Member State applies the following rules being the basis of application of this TSI:

1) Parts and basic parameters of the subsystem, that the modernization works are not affected, are excluded from the assessment of conformity with the rules of this TSI.

2) A new assessment with paying special attention to the requirements of this TSI is required only for those basic parameters in this TSI, which are changed as a result of the modification.

3) In the case when during the modernization the requirement of the TSI for economic reasons cannot be met, the modernization is acceptable as long as it is clear that the basic parameter is improved in the direction specified in the TSI.

4) In the instructions of application there are the guidelines for the Member States concerning those modifications that are accepted as modernized.

5) The domestic migration strategies related to the implementation of other TSIs (e.g. TSIs including the fixed installations) may impact on the required scope of using of this TSI.

6) In the case of a project including elements incompatible with TSI, the conformity assessment procedures and EC verification, which were to be applied, should be agreed with the Member State.

The above provisions relating to the modernization and renewal have the status binding directly in the Member State. The most important provision for both the renewal and modernization is that checking of the vehicle after the carried out modernization should take place within the scope of the introduced changes. This means that even though some parameters may not meet the requirements applicable at the time of the modernization, they will not be subject to assessment. The assessment of changes should be carried out comprehensively on the basis of a common method of safety assessment in the range of the valuation and risk assessment. The results of the valuation and risk assessment lead to carry out the checks in the systems in which the change was not carried out. An example might be the changes of the interior of the vehicle 
tym wydaje się sprawdzenie pod kątem wymagań palności zastosowanych materiałów czy dostosowaniu przedziałów dla osób niepełnosprawnych a tak że sprawdzenie wymagań środowiskowych. Ponieważ zmiany nie dotyczyły układu hamulca może się wydawać, że nie potrzeba przeprowadzać sprawdzeń w tym układzie. Prawidłowo przeprowadzona ocena bezpieczeństwa może jednak wykazać, że zmiana masy pojazdu $\mathrm{w}$ związku $\mathrm{z}$ wprowadzonymi zmianami jest na tyle istotna, że badania hamulca muszą zostać wykonane. Powyższy przykład obrazuje, jak istotny jest proces oceny bezpieczeństwa oraz kompleksowe podejście do podsystemu. Drugi istotny zapis mówi o dążeniu w kierunku wskazanym przez TSI. Wymaganie ma istotny wpływ na przeprowadzane procesy modernizacji i odnowienia. Jako przykład mogą posłużyć wszelkie zmiany, które wymagały by wprowadzenia znaczących zmian w konstrukcji pudła takie jak wielkość otworów drzwiowych. Jeżeli modernizowany tabor posiada otwory drzwiowe, które nie spełniają wymagań obecnie obowiązujących TSI to modernizacja nie powinna pogorszyć tej sytuacji. Oznacza to, że nie ma konieczności przerabiania konstrukcji szkieletu pudła, które wiązać się może z powtarzaniem statycznych badań wytrzymałości pudła, ale nowo zamontowane drzwi nie mogą pozostawiać mniejszej przestrzeni niż stosowane przed modernizacją. Wszelka zmiana parametrów powinna zbliżać konstrukcję do rozwiązań podanych w TSI. Należy zwrócić uwagę, że powyższe przykłady nie są jednoznacznymi wskazówkami do prowadzonych ocen i każdorazowo autorzy modernizacji muszą kompleksowo rozpatrzyć wpływ zmian na bezpieczeństwo.

\section{PRZEPISY KRAJOWE}

Przepisy krajowe, jak już wcześniej przedstawiono, biorą swój początek w prawie wspólnotowym. Głównym aktem prawnym formułującym podstawowe zasady homologacji pojazdów szynowych w Polsce jest Ustawa o transporcie kolejowym [9]. W ustawie $\mathrm{w}$ artykule 4 podano podstawowe definicje odnoszące się do modernizacji i odnowienia:

Art. 4. Użyte w ustawie określenia oznaczaja:

43) modernizacja - większe prace modyfikacyjne wykonywane $w$ podsystemie lub $w$ jego czesści, poprawiajace całkowite osiagi podsystemu;

44) odnowienie - większe prace wymienne $w$ podsystemie lub $w$ części podsystemu, które nie zmieniaja calkowitych osiagów podsystemu;

Definicje są zaczerpnięte z dyrektywy [5] i odnoszą się do wszystkich pojazdów kolejowych w Polsce, które podlegają ocenie zgodnie z Rozporządzeniem w sprawie interoperacyjności systemu kolei [10] jak i rozporządzeniu $\mathrm{w}$ sprawie dopuszczania do eksploatacji określonych rodzajów budowli, urządzeń i po- improving the riding comfort. The replacement involves the replacement of lining of the walls and floors, the seats, building in of air conditioners, building in of a new toilet. It seems obvious to check the requirements for flammability of used materials or adjusting the compartments for the disabled as well as the verification of environmental requirements. As the changes didn't concern the brake system it may seem that there is no need to carry out checks in the system. However, the corrected carried out safety assessment may show that the change of weight of the vehicle, because of introduced changes, is significant enough that the brake tests must be performed. The above example illustrates how important is the process of safety assessment and the comprehensive approach to the subsystem. The second important provision speaks about striving in the direction indicated by the TSI. The requirement has a significant impact on the carried out processes of modernization and renewal. As an example any changes may serve that would require making the significant changes in the structure of the body, such as the size of door openings. If a modernized rolling stock has door openings that do not meet the requirements of the existing TSI, the modernization should not worsen this situation. This means that it is not necessary to process the body shell that can be connected with the repetition of the static strength test of the body, but the newly installed door cannot leave the less space than those used before the modernization. Any change of parameters should approach the construction to the solutions specified in the TSI. It should be noted that the above examples are not unambiguous guidelines for the carried out assessments and every time the authors of modernization must comprehensively consider the impact of changes on safety.

\section{NATIONAL REGULATIONS}

As it was previously presented the national regulations have their origin in Community law. The main legal instrument formulating the basic rules for railway vehicles approval in Poland is the Act on railway transport [9]. In the Act in Article 4 the basic definitions relating to the modernization and renewal are given:

Art. 4 The used in this Act terms mean:

43) modernization - major modification works carrying out in the subsystem or its part, which improve the overall performance of the subsystem;

44) renewal-major replaceable works in the subsystem or in the part of subsystem which do not change the overall performance of the subsystem;

Definitions are taken from the Directive [5] and relate to all rail vehicles in Poland which are subject to assessment in accordance with the Regulation on the interoperability of the rail system [10] and the 
jazdów kolejowych [11]. Informacje na temat modernizacji zostały przedstawione $\mathrm{w}$ artykule 23i Ustawy [9]:

1. W przypadku modernizacji pojazdu kolejowego jest wymagane uzyskanie nowego zezwolenia na dopuszczenie do eksploatacji.

2. Do uzyskania zezwolenia na dopuszczenie do eksploatacji, o którym mowa w ust. 1, stosuje się art. $23 b$.

3. Dysponent albo producent pojazdu kolejowego może złożyć do Prezesa UTK wniosek o zgodę na odstapienie od konieczności uzyskania nowego zezwolenia na dopuszczenie do eksploatacji.

4. Prezes UTK, $w$ drodze decyzji, wyraża zgode, o której mowa $w$ ust. 3, jeżeli modernizacja nie powoduje zmian wptywajacych na bezpieczeństwo transportu kolejowego lub zgodność z siecia kolejowa, na której będzie eksploatowany pojazd kolejowy.

Zapisy artykułu 23i Ustawy [9] nakazują w przypad$\mathrm{ku}$ modernizacji wystąpienie do Prezesa Urzędu Transportu Kolejowego o wydanie nowego zezwolenia lub o wydanie decyzji pozwalającej modernizowanemu pojazdowi poruszanie się po sieci kolejowej na podstawie posiadanego przed modernizacją dokumentu dopuszczającego do ruchu.

Szczegółowe informacje dotyczące modernizacji lub odnowienia zostały przedstawione $\mathrm{w}$ rozporządzeniach [10], [11]. W Rozporządzenie [10] odnosi się do wszystkich linii kolejowych w Polsce (zarówno $1435 \mathrm{~mm}$ oraz linii $1520 \mathrm{~mm}$ ) i obejmuje swoim zasięgiem zarówno pojazdy zgodne z TSI jak i pojazdy niezgodne z TSI. Rozporządzenie [10] w paragrafie 2 wprowadza również „nowe” pojęcie „,modyfikacji”.

Zgodnie z zapisami [10] modyfikacja to:

...wszelkie zmiany wprowadzane $w$ dopuszczonym do eksploatacji podsystemie strukturalnym, objętym deklaracja weryfikacji WE podsystemu, do których należa:

a) zmiany wynikajace $z$ wymiany $w$ ramach utrzymania oraz inne zmiany, które nie wiaża się z odstępstwem od zapisów dokumentacji technicznej dołaczanej do deklaracji weryfikacji WE podsystemu,

b) zmiany inne niż wynikajace z modernizacji lub odnowienia, które wiaża się z odstępstwem od zapisów dokumentacji technicznej dołaczanej do deklaracji weryfikacji WE podsystemu, oraz nie maja żadnego wptywu na zasadnicze cechy konstrukcyjne podsystemu istotne dla zapewnienia zgodności podsystemu z parametrami podstawowymi,

c) zmiany inne niż wynikajace z modernizacji lub odnowienia, które wiqża się z odstępstwem od zapisów dokumentacji technicznej dołaczanej do deklaracji weryfikacji WE podsystemu,
Regulation on acceptance of certain types of buildings, equipment and rail vehicles [11] for placing in service. Information on the modernization are presented in the article $23 i$ of the Act [9].

Art. 23i.

1. In the case of modernization of a railway vehicle it is required to obtain a new authorization for placing in service.

2. To obtain the authorization for placing in service as referred to in paragraph 1, it is applied art. $23 b$.

3. Administrator or producer of railway vehicle may submit to the President of UTK (the Office of Railway Transport) the application for approval for withdrawal from the necessity to obtain a new authorization for placing in service.

4. The President of UTK consents by the decision, referred to in paragraph. 3 , if the modernization does not cause the changes affecting the safety of railway transport or the conformity with the railway network, on which the railway vehicle will be operated.

The provisions of Article 23i of the Act [9] require in the case of modernization to request the President of the Office of Railway Transport to issue a new permission or to issue a decision allowing the modernized vehicle moving on the railway network on the basis of owned before modernization document allowing move.

The detailed information on modernization or renewal is presented in the Regulations [10], [11]. The Regulation [10] applies to all railway lines in Poland (both $1435 \mathrm{~mm}$ and $1520 \mathrm{~mm}$ lines) and covers with its scope both vehicles compatible with the TSI and the vehicles incompatible with the TSI. Regulation [10] in section 2 also introduces the "new" term of "modification". In accordance with the notes of [10] modification is:

modification - any changes introduced in the authorized structural subsystem for placing in service, covered by the EC declaration of verification of the subsystem, which include:

a) changes resulting from the exchange as part of maintenance and other changes that do not involve exception from the provisions of the technical documentation attached to the $E C$ declaration of verification of the subsystem

b) changes other than those arising from the modernization or renewal, which relate to the exception from the provisions of the 
oraz maja wplyw na zasadnicze cechy konstrukcyjne podsystemu istotne dla zapewnienia zgodności podsystemu $z$ parametrami podstawowymi.

Zasady postępowania w przypadkach b) i c) opisuje szczegółowo §10. Zgodnie z $\$ 10$ należy wykazać wpływ modyfikacji na zasadnicze cechy konstrukcyjne podsystemu, które są istotne dla zgodności z parametrami podstawowym. Parametry podstawowe to wymagania prawne, techniczne i eksploatacyjne określone w TSI [10]. W §10 nie ma informacji, w jaki sposób dokonać oceny wpływu przeprowadzonych zmian na bezpieczeństwo. Narzędziem, które można wykorzystać do przeprowadzenia oceny jest analiza przeprowadzona $\mathrm{w}$ oparciu o wspólną metodę oceny bezpieczeństwa w zakresie wyceny i oceny ryzyka. Zasady jej przeprowadzenia podaje Rozporządzenie [7]. Analiza ryzyka prowadzona zgodnie z przepisami prawa jest istotnym narzędziem dla zachowania bezpieczeństwa $\mathrm{w}$ systemie kolei. Analiza ryzyka ma istotne znaczenie również przy ubieganiu się o wydanie zezwolenia dla pojazdu przy ograniczony zakresie badań. Zgodnie z $§ 13$ rozporządzenia [10] wnioskodawca może ubiegać się o ograniczenie badań.

1. Na wniosek podmiotu ubiegajacego się o wydanie zezwolenia na dopuszczenie do eksploatacji pojazdu kolejowego niezgodnego z TSI wykaz parametrów określonych $w$ załaczniku $n r 4$ do rozporzqdzenia może zostać ograniczony przez Prezesa Urzędu Transportu Kolejowego, gdy spetnione zostana tacznie nastęujace warunki:

1) modernizowany typ pojazdu kolejowego posiada świadectwo dopuszczenia do eksploatacji typu, zezwolenie na dopuszczenie do eksploatacji, lub inny dokument potwierdzajacy dopuszczenie do eksploatacji $w$ innym państwie czlonkowskim Unii Europejskiej lub w ruchu międzynarodowym;

2) możliwość ograniczenia zakresu parametrów została wykazana przez podmiot ubiegajacy się o wydanie zezwolenia na dopuszczenie do eksploatacji pojazdu kolejowego niezgodnego z TSI w ramach procesu oceny ryzyka przeprowadzonego zgodnie z przepisami Komisji Europejskiej dotyczacymi wspólnej metody oceny bezpieczeństwa $w$ zakresie wyceny i oceny ryzyka;

3) podmiot uprawniony pozytywnie zaopiniowat możliwość ograniczenia zakresu parametrów koniecznych do skontrolowania $i$ określit ich wymagany zakres.

2. Zakres ograniczenia, o którym mowa $w$ ust. 1 , nie może obejmować parametrów odnoszacych się do tych elementów typu pojazdu kolejowego, które zostały poddane modernizacji, i uktadów, na które modernizacja ma bezpośredni wptyw. technical documentation attached to the $E C$ declaration of verification of the subsystem, and have no impact on the basic design characteristics of the subsystem essential to ensure the conformity of the subsystem with the basic parameters,

c) changes other than those arising from the modernization or renewal, which relate to the exception from the provisions of the technical documentation attached to the $E C$ declaration of verification of the subsystem, as well as affect the basic design characteristics of the subsystem essential to ensure the conformity of the subsystem with the basic parameters

The rules of conducting in cases b) and c) are described in detail in $\S 10$. According to $\S 10$ it should be demonstrated the effect of modifications on the basic design characteristics of the subsystem, which are essential for conformity with the basic parameters. The basic parameters are legal, technical and operational requirements specified in the TSI [10]. In $\S 10$ there is no information on how to assess the impact of introduced changes on safety. A tool that can be used to assess is the analysis carried out on the basis of a common safety method in the range of valuation and risk assessment. The rules of conducting are given in Regulation [7]. The risk analysis carried out in accordance with the law is an important tool for maintaining the safety of the railway system. The risk analysis is also important during applying for a permission for the vehicle with limited range of tests. According to $\S 13$ of Regulation [10] the applicant can apply for a reduction of tests.

\section{$\S 13$.}

1. At the request of the entity applying for authorization of a railway vehicle incompatible with the TSI for placing in service, the list of parameters defined in Annex 4 to the regulation may be limited by the President of the Office of Railway Transport when the following conditions are met altogether:

1) modernized type of railway vehicle has certificate of the authorization of type for placing in service, the permission for the authorization for placing in service or other document confirming the authorization for placing in service in another Member State of the European Union or in the international traffic

2) the possibility of limitation of the scope of the parameters was demonstrated by the entity applying for authorization of a nonTSI compliant railway vehicle for placing 
Powyższe zapisy zwracają uwage na dwa istotne elementy. Zgodnie z pkt. 1 tylko Prezes Urzędu Transportu Kolejowego może ograniczyć badania już dopuszczonego pojazdu a poddanego modernizacji. Drugim istotnym elementem jest prawidłowe wykonanie wyceny i oceny ryzyka. Prawidłowo przeprowadzona analiza ryzyka jest źródłem informacji na temat możliwych zagrożeń, co przyczynia się do prawidłowego monitorowania źródeł powstawania zagrożeń oraz umożliwia właściwe przeciwdziałanie skutkom ewentualnych zdarzeń. Niestety nawet najlepiej wykonana analiza ryzyka nie gwarantuje pełnego bezpieczeństwa. Aby maksymalnie zwiększyć poziom bezpieczeństwa oraz analiza ryzyka była prawidłowo wykonana (maksymalnie ograniczała skutki awarii) niezbędne jest bezustanne monitorowanie systemu bezpieczeństwa i rozwijanie go w oparciu o nowe doświadczenia.

Kolejnym aktem prawnym obowiązującym w Polsce a odnoszącym się do homologacji pojazdów kolejowych jest Rozporządzenie w sprawie dopuszczania do eksploatacji określonych rodzajów budowli, urządzeń i pojazdów kolejowych [11]. Rozporządzenie to odnosi się do pojazdów poruszających się na bocznicy, pojazdów metra, pojazdów poruszających się po infrastrukturze o szerokości toru mniejszej niż $1435 \mathrm{~mm}$ oraz po liniach wydzielonych. Zgodnie $\mathrm{z}$ rozporządzeniem [11] w przypadku modernizacji spełnione muszą być warunki podane w $\S 17$ :

$\mathrm{Na}$ wniosek podmiotu ubiegającego się o wydanie świadectwa dopuszczenia do eksploatacji typu zakres badań technicznych, o których mowa w niniejszym rozdziale, może być ograniczony przez Prezesa UTK, w przypadku, gdy typ spełnia następujące warunki:

1) Posiada certyfikaty uprawnionych jednostek badawczych krajowych lub majacych siedzibe na terytorium państw członkowskich Unii Europejskiej,

2) Byt badany zgodnie z zakresem wymienionym $w$ rozporzadzeniu, posiada raporty potwierdzajace pozytywne wyniki badań i jest eksploatowany na terytorium państw członkowskich Unii Europejskiej,

3) Posiada pozytywne opinie użytkowników z dotychczasowej eksploatacji, lub

4) Typ pojazdu kolejowego jest przeznaczony do modernizacji.

Modernizacja jest więc przesłanką do tego, aby ograniczyć zakres badań dla pojazdów, ale podobnie jak w przypadku poprzednich rozporządzeń [8], [10] niezbędne jest wykonanie stosownych analiz (ocena i wycena ryzyka) i nie można pomijać przeprowadzenia badań w obszarach modernizowanych.

\section{WNIOSKI}

Analiza tekstów rozporządzeń pozwala na wyciągnięcie wniosku, że jednym z najistotniejszych in service within the process of risk assessment carried out in accordance with the provisions of the European Commission on a common method of safety assessment in the range of valuation and risk assessment;

3) the authorized entity gave a positive opinion on the possibility of limiting the scope of the parameters necessity to control and specified their required range.

2. The scope of limitation, referred to in paragraph 1, cannot include the parameters relating to these elements of a type of railway vehicle which were subjected to modernization, and systems on which modernization has a direct impact.

The above provisions take notice of two important elements. In accordance with paragraph 1 , only the President of the Office of Railway Transport can limit the tests already authorized vehicle and subjected to modernization. Another important element is the correct execution of valuation and risk assessment. The correctly carried out risk analysis is a source of information on the possible threats, which contributes to the correct monitoring of the sources of occurring the threats, and enables the appropriate counteract the effects of possible events. Unfortunately, even the best-made risk analysis does not guarantee the complete safety. To maximize the level of safety and to carry out the risk analysis correctly (it maximally limited the effects of the damage), it is necessary to constantly monitor the security system and develop it based on the new experiences.

Another legal act applicable in Poland and relating to the approval of railway vehicles is the Regulation on acceptance of certain types of buildings, equipment and rail vehicles [11] for placing in service. This regulation applies to the vehicles moving on the siding, the metro vehicles, the vehicles moving on the infrastructure with a track width of less than $1,435 \mathrm{~mm}$ and the dedicated lines. According to the Regulation [11] in the case of modernization the conditions specified in $\S 17$ must be met:

\section{$\S 17$.}

At the request of the entity applying for a certificate of the authorization for placing in service of type the range of technical tests, referred to in this Chapter, may be limited by the President of Office of Railway Transport (UTK), where the type meets the following conditions:

1) It has the certificates of the authorized national research bodies or having the registered office on the territory of the Member States of the European Union, 
elementów pracy, którą należy wykonać podczas modernizacji lub odnowienia jest analiz ryzyka. Właściwie wykonana ocena i wycena ryzyka pozwala na zachowanie odpowiedniego poziomu bezpieczeństwa. Nierozstrzygniętą kwestią pozostaje precyzyjne rozróżnienie pomiędzy modernizacją a odnowieniem. Brak jest jednoznacznie określonych parametrów, których zmiana powoduje konieczność zastosowania procedur adekwatnych dla modernizacji lub odnowienia. W samych dokumentach często można znaleźć zrównanie tych pojęć już na poziomie definicji. Poniżej przedstawiono fragment $\mathrm{z}$ zaleceń komisji odnoszący się do modernizacji i odnowienia [12]:

\section{ZARZA¿DANIE MODYFIKACJAMI}

110. Uwzględniajac zastosowanie art. 5 ust. 2, art. 15 ust. 3 i art. 20 dyrektywy 2008/57/WE wszelkie modyfikacje istniejacych podsystemów strukturalnych należy przeanalizować $i$ zaszeregować wytacznie do jednej z nastepujacych modyfikacji:

1) „wymiana $w$ ramach utrzymania" $i$ inne zmiany, które nie wiqża się z odstęstwem od dokumentacji technicznej towarzyszqcej deklaracji weryfikacji WE. W tym przypadku nie ma potrzeby weryfikacji przez jednostke oceniajaca, nie ma potrzeby informowania państwa członkowskiego, a poczqtkowa deklaracja weryfikacji WE pozostaje wazna i niezmieniona;

2) zmiany wiażace się z odstęstwem od dokumentacji technicznej towarzyszacej deklaracji weryfikacji WE, które moga wymagać nowych kontroli ( $i$ w zwiazku z tym wymagaja weryfikacji zgodnie ze stosownymi modułami oceny zgodności), ale nie maja żadnego wplywu na zasadnicze cechy konstrukcyjne podsystemu. $W$ tym przypadku należy zaktualizować dokumentacje technicznq towarzyszaca deklaracji weryfikacji WE i udostępnić odpowiednie informacje na żadanie odpowiedniego krajowego organu ds. bezpieczeństwa;

3) odnowienie lub modernizacja (np. większa wymiana lub zmiana wymagajaca poinformowania państwa czlonkowskiego), które nie wymagaja nowego zezwolenia na dopuszczenie do eksploatacji; modyfikacje, których zakres obejmuje zmiane zasadniczych cech konstrukcyjnych podsystemu, zaliczaja się do tej kategorii;

4) odnowienie lub modernizacja (np. większa wymiana lub zmiana wymagajaca poinformowania państwa czlonkowskiego), które wymagaja nowego zezwolenia na dopuszczenie do eksploatacji.
2. It was tested in accordance with the scope given in the Regulation, it has the reports confirming the positive results of tests and it is operated on the territory of the Member States of the European Union,

3. It has the positive opinions of user from the current operation, or

4. The type of railway vehicle is intended for modernization.

Therefore, the modernization is a prerequisite for this to limit the scope of tests of vehicles, but similarly as in the previous regulations [8], [10] it is necessary to perform the appropriate analysis (assessment and risk valuation) and it cannot be ignored tests in the areas of modernization.

\section{CONCLUSIONS}

The analysis of texts of regulations allows draw the conclusion that one of the most important elements of the work, which must be performed during the modernization or renewal, is the risk analysis. The correctly carried out assessment and risk valuation allows to maintain an appropriate level of safety.

The unresolved issue is the precise differentiate between the modernization and the renewal. There are no clearly defined parameters, whose change causes the necessity of using the adequate procedures for modernization or renewal. Only in the documents it can be often found the equaling of these terms at the level of definition. Below there is a fragment of the recommendations of the Commission relating to the modernization and renewal [12]:

\section{MODIFICATIONS MANAGEMENTS}

110. Taking into account the application of Article 5 paragraph 2, Art. 15 paragraph 3 and Art. 20 of Directive 2008/57/EC any modifications of the existing structural subsystems must be analyzed and classified only to one of the following modifications:

1) „replacement within the maintenance" and other changes that do not involve the exception from the technical documentation attached to the EC declaration of verification. In this case there is no need for verification by the assessment body, there is no need to inform the Member State, and the initial EC declaration of verification remains valid and unchanged;

2) the changes that do not involve the exception of the technical documentation attached to the $E C$ declaration of verification which may require the new controls (and therefore they require the verification in accordance with the applicable conformity assessment modules), 
Zalecenie to akt prawny, który nie ma mocy wiążącej ale wyraża stanowisko Unii Europejskiej w konkretnej sprawie lub dziedzinie. Jednak w przypadku odnowienia lub modernizacji (modyfikacji) stanowisko nie pozwala rozgraniczyć pojęć podstawowych. Rozgraniczenie pojęć modernizacji i odnowienia ma istotny wpływ na podejmowanie działań pozwalających uzyskanie odpowiednich zezwoleń dopuszczajacych pojazdy do ruchu. Koniecznym jest więc podjęcie prac, które doprowadzą do stworzenia listy parametrów, które pozwolą jednoznacznie odróżnić modernizację od odnowienia.

\section{BIBLIOGRAFIA}

[1] https://pl.wikipedia.org/wiki/EN57

[2] http://kolej.darlex.pl/index.php?option=com_conten $t \&$ view $=$ article\&id $=443 \&$ Itemid $=512$

[3] https://pl.wikipedia.org/wiki/PKP_Szybka_Kolej_Mi ejska_w_Tr\%C3\%B3jmie\%C5\%9Bcie

[4] Szymajda M.: Czy modernizacje EN57 maja sens? Rynek Kolejowy 3/2016.

[5] Dyrektywa Parlamentu Europejskiego $i$ Rady 2008/57/WE z dnia 17 czerwca 2008 r. w sprawie interoperacyjności systemu kolei we Wspólnocie [5],

[6] Dyrektywa 2004/49/WE Parlamentu Europejskiego $i$ Rady z dnia 29 kwietnia 2004 r. w sprawie bezpieczeństwa kolei wspólnotowych oraz zmieniajaca dyrektywę Rady 95/18/WE w sprawie przyznawania licencji przedsiębiorstwom kolejowym, oraz dyrektywe 2001/14/WE w sprawie alokacji zdolności przepustowej infrastruktury kolejowej $i$ pobierania optat za użytkowanie infrastruktury kolejowej oraz certyfikację $w$ zakresie bezpieczeństwa [6].

[7] Rozporzqdzenie Wykonawcze Komisji (UE) $n r$ 402/2013 z dnia 30 kwietnia 2013 r. w sprawie wspólnej metody oceny bezpieczeństwa $w$ zakresie wyceny $i$ oceny ryzyka $i$ uchylajace rozporzadzenie (WE) $n r$ 352/2009.

[8] Rozporzqdzenie Komisji (UE) nr 1302/2014 z dnia 18 listopada 2014 r. $w$ sprawie technicznej specyfikacji interoperacyjności odnoszqcej się do podsystemu „Tabor — lokomotywy $i$ tabor pasażerski” systemu kolei w Unii Europejskiej.

[9] Ustawa z dnia 28 marca 2003 r. o transporcie kolejowym (Dz. U. 2015 poz.1297).

[10] Rozporzqdzenie Ministra Infrastruktury $i$ Budownictwa z dnia 25 lutego 2016 r. w sprawie interoperacyjności systemu kolei (Dz. U. 2016 poz.254).

[11] Rozporzqdzenie Ministra Infrastruktury i Rozwoju z dnia 13 maja 2014 r. w sprawie dopuszczania do eksploatacji określonych rodzajów budowli, urzqdzeń i pojazdów kolejowych (Dz. U. 2014 poz. 720).

[12] Zalecenie Komisji z dnia 5 grudnia 2014 r. w sprawie kwestii z dopuszczeniem do eksploatacji $i$ użytkowaniem podsystemów strukturalnych $i$ pojazdów na podstawie dyrektywy Parlamentu Europejskiego i Rady 2008/57/WE i 2004/49/WE (2014/897/UE).
3) but they have no impact on the basic design characteristics of the subsystem. In this case the technical documentation attached to the EC declaration of verification should be updated and the relevant information at the request of the relevant national authority of safety should be available;

4) the renewal or modernization (e.g. the bigger replacement or modification requiring to inform the Member State) that does not require the new authorization for placing in service; the modifications whose scope includes changing of the essential design characteristics of the subsystem, are included in this category;

The recommendation is a legal act, which is not binding, but expresses the position of the European Union in a specific case or field. However, in the case of renewal or modernization (modification) the position does not allow distinguish the basic terms. The differentiation of the terms of modernization and renewal has a significant impact on taking activities to obtain the appropriate permissions allowing vehicles to move. Therefore, it is necessary to undertake the works that will lead to the creation of a list of parameters that will clearly distinguish the modernization from the renewal. 